\title{
RECONSTRUCTION OF LOCAL ENVIRONMENTS OF ANCIENT POPULATION IN A CHANGEABLE RIVER VALLEY LANDSCAPE (THE MIDDLE VYCHEGDA RIVER, NORTHERN RUSSIA)
}

\author{
VICTOR N. KARMANOV ${ }^{1}$, NATALIA E. ZARETSKAYA ${ }^{2}$, ANDREY V. PANIN ${ }^{3}$ and ALEXEY V. CHERNOV ${ }^{3}$ \\ ${ }^{I}$ Institute of Language, Literature and History of Komi Science Center of Ural Division of Russian Academy of Sciences, \\ Kommunisticheskaya st., 26; 167982, Syktyvkar, Republic of Komi, Russian Federation \\ ${ }^{2}$ Geological Institute of Russian Academy of Sciences, Pyzhevsky per., 7, 119017, Moscow, Russia \\ ${ }^{3}$ Moscow State University, Faculty of Geography, Lengory-1, 119991, Moscow, Russia
}

Received 21 June $2010 \quad$ Accepted 25 November 2010

\begin{abstract}
In river valleys, both human occupation and subsequent preservation of archaeological sites are affected by active landscape transformation caused by river lateral migration, incision/aggradation cycles and changes of river hydrological regime. In the middle Vychegda River valley (Northern Russia), there are numerous traces of human presence since the Mesolithic. We exploit multi-disciplinary archaeological, geomorphological and geochronological approach to elucidate the environmental preferences of settlements positioning during different epochs of the Holocene. High resolution space image supplemented with data on alluvial stratigraphy derived from bank exposures and hand cores, as well as 51 radiocarbon dates were used to make the geomorphic map showing ages of floodplain/terrace segments and palaeochannels. Using this map together with sediment facial interpretation, position of archaeological sites was analysed in the context of local geomorphic and hydrologic situation. The majority of archaeological sites and modern settlements are found on terraces at river banks or at oxbow lakes which were well connected to the river. Few exceptions from this rule may be explained by seasonal character of dwelling functioning, ritual burial practice or specialization of settlements. Geomorphic situation was used as a background for planning further prospection of different-age archaeological objects.
\end{abstract}

Keywords: Vychegda River, alluvial geoarchaeology, Mesolithic, Neolithic, Holocene, fluvial geomorphology, palaeochannel, palaeohydrology, geomorphic mapping, radiocarbon dating.

\section{INTRODUCTION}

Reconstruction of environmental conditions of ancient population is a necessary component of archaeological studies. Much information on adaptation and subsistence of human communities comes from investigations of wetland sites. However, such kind of archaeological sites is seldom in some regions, which depends on geograph-

Corresponding author: V. N. Karmanov

e-mail: vkarman@bk.ru ical peculiarities and characteristics of historical development of a specific territory. The Far North-East of Europe is one of such areas (Fig. 1). Most sites and historical settlements here are located on sandy highs of different origin on river floodplains and terraces. Understanding of age and origin of these highs, estimating location of river channel and other landscape features (lakes, bogs) in palaeotimes are necessary both for better planning of archaeological prospecting and for interpretation of results of excavations. 


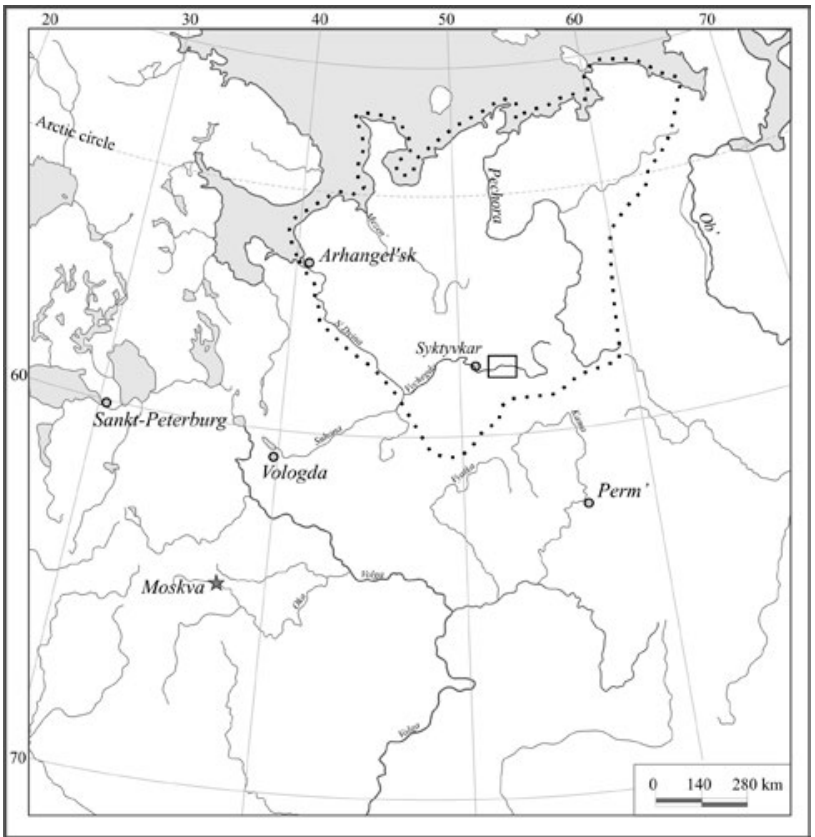

Fig. 1. Far European North-East (dotted line) and location of the study area (rectangle).

Archaeological studies in river valleys face with extremely changeable landscapes which could transform greatly between the periods of their occupation by humans. Great diversity of river valley landscapes makes it possible to meet specific preferences for location of settlements that could exist in a given culture. On the other hand, permanent reworking of valley floor, destruction of some areas and construction of other ones, poses limits on preservation of archaeological information. Therefore data on age of different valley floor segments and palaeochannels provides archaeologists with meaningful information for further prospection. Both aspects are long studied in the framework of alluvial archaeology (Howard et al., 2003), geoarchaeology of river valleys (Dobrzanska et al., 2004) and floodplain palaeoecology (Brown, 2003). In the Vychegda River valley, our study is the first one to exploit these approaches after a long time break. The first case of inter-disciplinary investigation in the region was the research by G. Burov near the Sindor Lake (rivers Simva and Vis) at the end of 1950-s. Along with archaeological results, stages of river channel development and local climate variability over the Holocene were evaluated (Burov, 1967). However, the absolute chronology was established by ${ }^{14} \mathrm{C}$ dating of wood samples only (Burov et al., 1972). In the beginning of 2000s, A. Volokitin carried out a research of Mesolithic sites formation and sources of flint raw material exploited by Mesolithic population (Volokitin and Tkachev, 2004).

Our own archaeological investigations have been conducted here since 2001 (Karmanov, 2008). Since 2002 we have been performing radiocarbon dating of samples from archaeological sites and peat bogs in the middle
Vychegda River valley, and since 2008 multi-disciplinary field studies have been performed (Volokitin et al., 2006; Zaretskaya et al., 2007; Zaretskaya et al., 2009). In the current work, we describe preliminary results of this research aimed at defining chronology of settling in the Vychegda valley and reconstruction of local landscapes of the settlements. We try to find explanations for the specific location of sites and probably on their seasonal functioning focusing on local palaeotopography and palaeohydrography. For example we took into account features of some Neolithic dwellings situation. They are located at the side of the terrace related to the peat bog and are hidden from it by dunes (Fig. 3).

\section{STUDY AREA}

Far North-East of Europe (FNEE) is limited in the north by the Barents Sea coast, in the east - by the Ural Mountains, in the south - by the Severnye Uvaly Upland and in the west - by the Severnaya Dvina River. It is a territory of Komi Republic, Eastern Archangelsk Region (Fig. 1). Large latitudinal and longitudinal extent, heterogeneous geological structure and relief resulted in great diversity of natural condition. The extreme northernmost part of the region is located in tundra zone, the west is taiga. Geomorphologically FNEE is separated into two parts: the eastern margin belongs to the Ural mountains and the western part to the Russian Plain. The region is characterized by dense drainage net and is divided between three main river basins: Pechora, Mezen' and Vychegda (North Dvina basin). The area of our investigation is located in the middle Vychegda River valley about $60 \mathrm{~km}$ upstream from the Syktyvkar city at the Pezmog and Priozernyj villages (Fig. 2).

Vychegda River has latitudinal direction and drains hilly terrain covered by dense coniferous forests with abundant swamps. The climate is humid with long cold winters. The river's hydrological regime is characterized by high spring flood which passes some $60-70 \%$ of annual runoff and much lower episodic rainfed floods in summer and autumn. The river has alluvial channel with free conditions for lateral migrations. In the Late Glacial and the Holocene the river has been changing its position on the valley bottom eroding terraces and valley slopes and constructing new floodplain segments. Morphology of these segments depends on channel type and hydrological conditions in the respective time span.

Diverse local landscapes such as peat bogs, dunes and sandy terrace remnants with forest and grass vegetation and oxbow lakes attracted human groups to their natural resources over the Holocene. The majority of archaeological sites and historical settlements are located on erosion remains of sandy river terraces, or so called "forested" terraces. Surfaces of most of them are fixed by welldeveloped podzolic soil and exhibit negligible artificial disturbance of alluvial stratigraphy. According to archaeological evidence, radiocarbon dating and historical rec- 


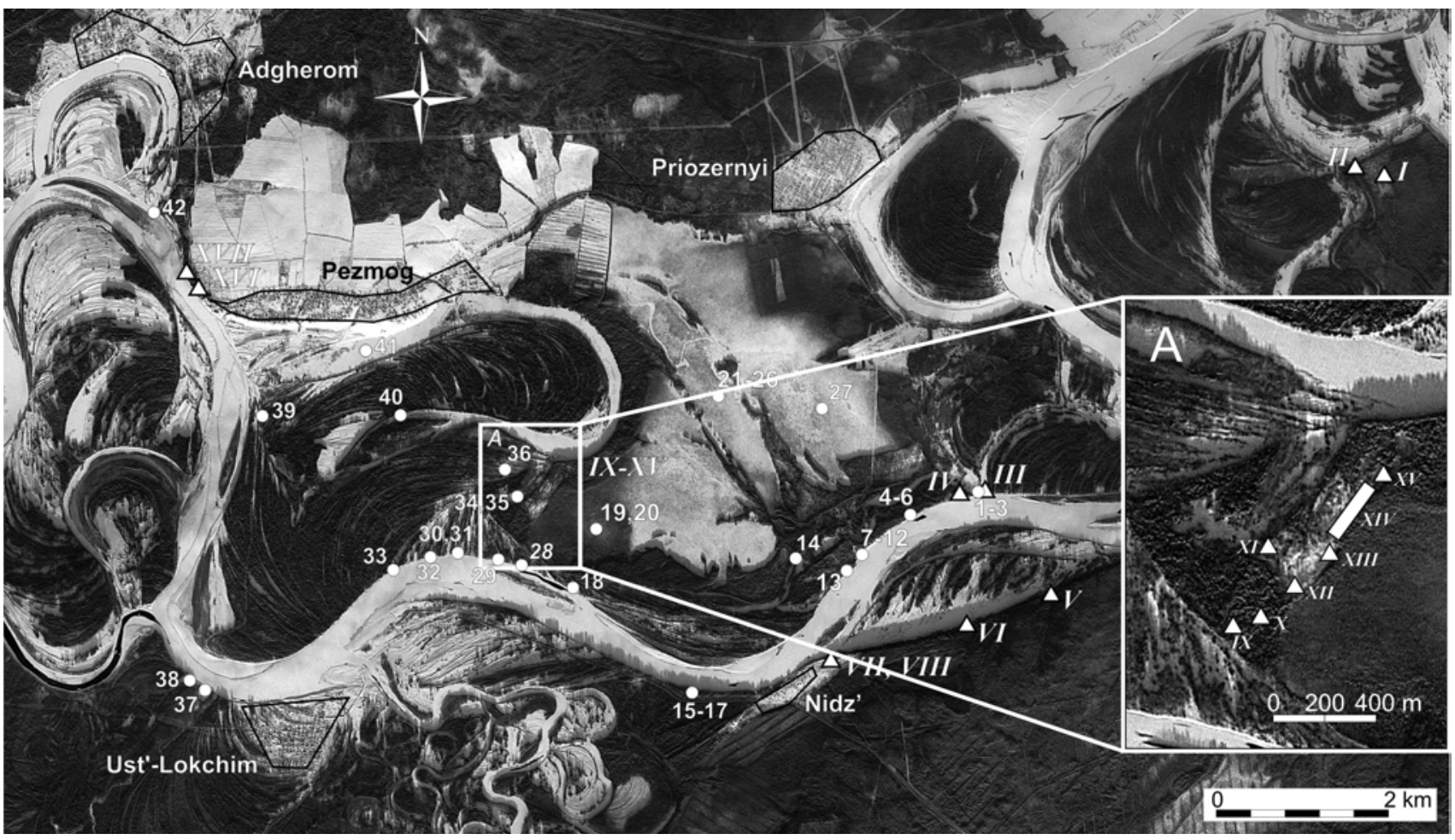

Fig. 2. Study area: archaeological sites (triangles) and modern settlements (white polygons) on satellite image (Alos Prism, $2.5 \mathrm{~m}$ ). Results of radiocarbon dating of different generations of flood plain. All dates by GIN-laboratory. Insert A: location of archaeological sites (triangles and rectangle) near Pezmogty lake. Archaeological sites: I, II - Vazhkur'ya 1, 2; III - Pezmog 4; IV - Pezmog 2; V - Mortshuyaty 2; VI - Mortshuyaty 1; VII, VIII Nidz' 1, 2; IX - Pezmogty 1; X - Pezmogty 2; XI - Pezmogty 3; XII - Pezmogty 6; XIII - Pezmogty 4; XIV - Pezmogskiy burial ground; $X V$ - Pezmogty $5 ; X V I-$ Pezmog 3; XVII - Pezmog 1.

ord, the key region was settled by different cultural and ethnic groups of population in the following periods (Figs. 2, 3):

1) Mesolithic (8310-7980 calBC). Evidence consists of remains of temporary hunter-gatherers' camps (Pezmog 1, Pezmogty 6) on the aeolian dunes or surface of the $1^{\text {st }}$ and $2^{\text {nd }}$ fluvial terraces (Burov, 1967);

2) Early Neolithic (5800-5710 calBC). Artefacts of hunter-gatherers' camp (Pezmog 4) were found in the buried oxbow deposits (Figs. 2 and 4);

3) Middle Neolithic (4710-4600 calBC). Remains of hunter-gatherers' dwellings (Figs. 2a, 3) (Pezmogty $1,3,4,5$ sites) were excavated at the base of aeolian dunes on the $1^{\text {st }}$ terrace surface (Karmanov, 2008);

4) Early Bronze Age (3940-2500 calBC). Flint workshop (Pezmogty 2) was studied on the deflation hollows on the $1^{\text {st }}$ terrace. Settlement with dwellings (Mortshuyaty 1) was discovered on the surface of $2^{\text {nd }}$ terrace (Korolev, 2005);

5) Medieval Ages (ca XII-XIII AD). Burial (Pezmog burial ground) of ancestors of modern komi occupied the aeolian dunes of $1^{\text {st }}$ terrace (Korolev, 1980);

6) Late Medieval (end of XVI c. AD). Foundation of komi farmers' village (Pezmog) took place on the $2^{\text {nd }}$ terrace (Zherebtsov, 2001);

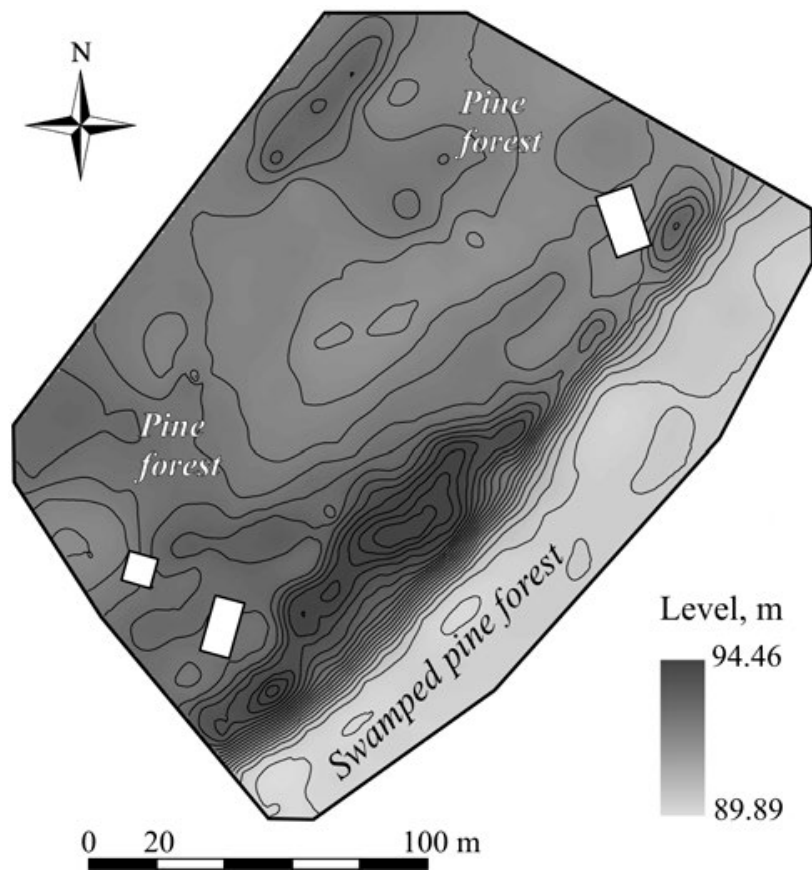

Fig. 3. Example of Neolithic dwellings situation (Pezmogty 3, 4 sites; $5840 \pm 100$ BP (GIN-11914). White square and rectangles mark excavations. 


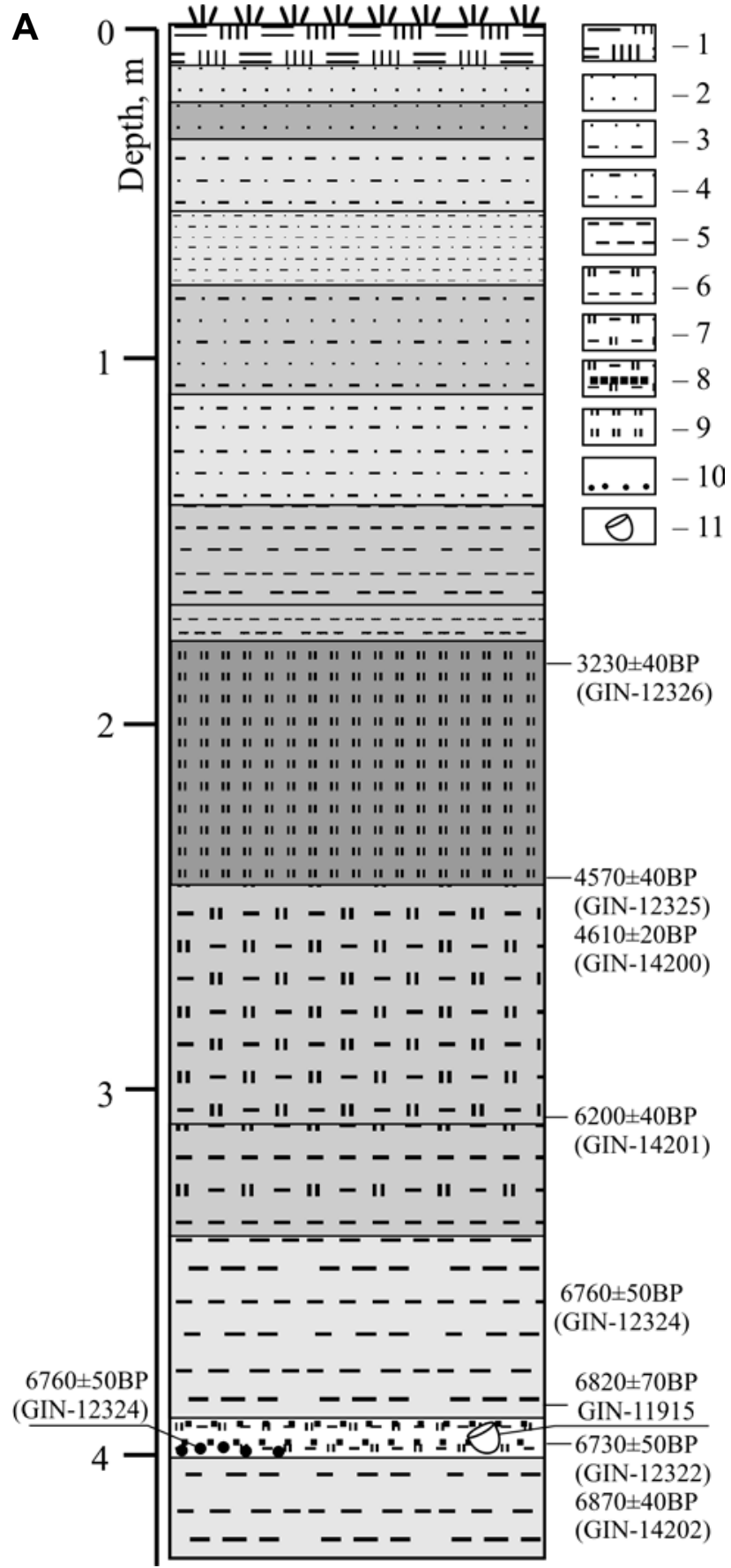

7) Modern times. In the middle of XX c. the loggers' settlements (so called special settlements of GULAG system) were organized on the bank of river and oxbow lakes on the flood plain segment (Ust'Lokchim) and $1^{\text {st }}$ (Adzherom, Priozernyj) and $2^{\text {nd }}$ (Nidz') terraces (Zherebtsov, 2001).

In general, the history of region settling is characterized by periodic occupation. We can define periods when the territory wasn't habited and even in the present time it
Fig. 4.

A: Pezmog IV site. Section. Results of radiocarbon dating.

1-turf;

2-sand;

3 - sandy loam/sand;

4 - sandy loam;

5 - clayey loam;

6 - loam with low content of peat;

7-loamy peat;

8 - loamy peat with sand (cultury-bearing layer);

9 - peat;

10 - charcoal fragments;

11 - vessel fragments

B: Pezmog 4. Results of radiocarbon dating. The results of direct dating of pottery are marked by grey

B

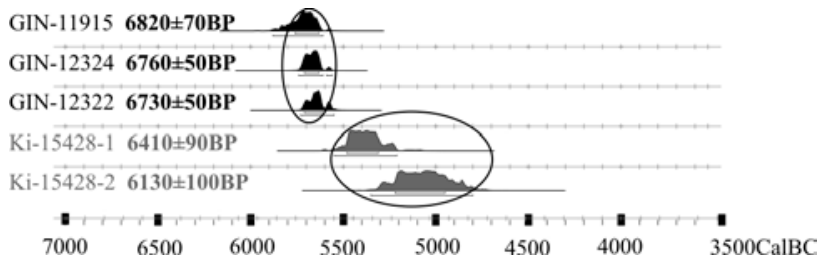

is a region with low density of population (Zagainova, 2001). Continuous habitation started at the beginning of $2^{\text {nd }} \mathrm{m}$. AD and people is regarded as ancestors of modern komi who were settling over the river valleys right up to XIX c. 


\section{METHODS}

In this research, we focus on development of river channel as the main factor of valley floor formation which defined the possibility of valley occupation by humans. Reconstruction of river history requires to study both, the valley bed morphology and the alluvial stratigraphy. When relative and absolute ages of the valley topography are established, they may be used for palaeoenvironmental evaluation at settlement locations. Given that methods of both fluvial geomorphology and archaeology can get "floating" chronological scales, absolute chronology of different phases of floodplain development and settlement functioning is necessary.

Given the above, the programme of inter-disciplinary research included the following:

1) Mapping of archaeological objects and modern settlements of different age;

2) Analysis of satellite images and topographic maps, making preliminary geomorphic map showing different age generations of palaeochannels, floodplain segments and fluvial terraces;

3) Field studies: a) visual detection of important landscape features, namely dunes, palaeochannels, leveehollow floodplain systems, etc.; b) studying alluvial stratigraphy by coring and outcrop observations; c) obtaining organic samples from certain stratigraphic positions important for reconstruction of palaeoenvironmental history, especially from bases of peat layers (beginning of bog development) and palaeochannel infills (dating the moment of palaeochannel abandonment); d) sampling for spore-pollen and botanic analysis and OSL dating; f) georadar survey to study morphology of palaeochannel bottoms and stratigraphy of sand terraces.

4) Radiocarbon dating of samples from different generations of floodplain;

5) Verification of relative ages of floodplain segments established by fluvial geomorphology methods, by radiocarbon dates and correction of the preliminary geomorphic map.

6) Palaeoenvironmental evaluation of known settlements based on their geomorphic position and stratigraphic data.

Except for commented specially, ages are given in radiocarbon years.

\section{RESULTS}

Two terraces (9-11 and 25-30 m high) and seven generations of floodplain (3-6 m high) are found in the valley floor (Fig. 5). Dated by ${ }^{14} \mathrm{C}$ were 51 organic samples (Table 1, Figs. 2, 4). From the point of environmental history two groups of dates are of primary importance. First, the dates that can be interpreted to closely represent the creation time of correspondent geomorphic units palaeochannels, leve-hollow sequences, etc. Palaeochan- nels are postdated by the age of alluvial infill that accumulated after palaeochannel abandonment. In cores, this infill is rather clearly distinguished by small grain size (silt, loam) compared to underlying active channel alluvium (sand). In floodplain segments with levee/hollow topography which were constructed by lateral accretion of convex meander banks, peat lenses are often enclosed into the hollows. Finish of point-bar sedimentation, which may be regarded as indicator of geomorphic completion of the site, is post-dated by the start of organic sedimentation. In both cases, the time elapsed between the end of active channel sedimentation and oxbow/overbank/organic sedimentation fixed by dated sample may vary and depends both on stratigraphical context and on local conditions. Therefore a series of dates within the same floodplain segment is needed to provide an age control. Terrace sands do not contain any radiocarbon datable matter. Where found, they are pre-dated by organic-rich loams buried under active channel sands. In these cases the youngest dates are most representative of terrace geomorphic age. Second group of dates includes those ones that date important environmental events such as transformation of fluvial into lacustrine, lacustrine into marshy environment. The most typical situation in the area is appearance of bogs indicated by peat sedimentation (dates on base of peat layers).

Fragment of the oldest (7th) floodplain generation was found at a single place, which does not allow reconstruction of the position of the river channel. The 6th floodplain generation formed in the Early Atlantic period (6560-6430 cal BC) is characterized by gentle curvature of levees. It was formed by low-sinuosity channel. In the 5th floodplain generation (Middle Atlantic, 5800-5710 cal BC) traces of river channel are poorly preserved. Nevertheless it is possible to establish that channel curvature was greater than it was in the previous period.

In the last floodplain generation channel traces are well pronounced which permits reconstruction of channel development since the beginning of the Subboreal till nowadays. The highest sinuosity is detected in the Early Subatlantic period (3rd generation, about 760-370 cal $\mathrm{BC})$. The end of the 3rd generation formation was marked by chute cut-off of several steep meanders due to probably one or a series of extreme hydrological events. Generations 2 and 1 mark growing of new meanders which have greater steps and channel width compared to the previous periods.

\section{DISCUSSION}

Putting archaeological sites and modern settlements on the geomorphic map provided information on palaeoenvironment conditions during the existence of certain groups of population and correspondence between historical and environmental development (Fig. 6).

1) Formation of the $1^{\text {st }}$ fluvial plain took place during the Younger Dryas (11370-9400 cal BC) in the cold 
conditions. That time the terrace was not forestcovered and was being reworked by aeolian action. The question we still cannot answer is when this surface had become stable and was occupied by vegetation. To solve it OSL dating of terrace and dunes is promising.

2) On one of the dunes, the Mesolithic camp (Pezmogty 6, Srednevychegodskaya culture, about 8310-7980 cal BC) was abandoned by people. Probably, they inhabited the bank of river during the warm season only (Fig. 6a).

3) At the Pezmog 4 site (Kamskaya culture), the culture-bearing layer is buried within clay and peat deposits (Figs. 4a, b). According to geomorphic data, the early Neolithic people occupied the bank of an oxbow lake, probably a promontory at the lake-river connection (Figs. 5, 6b). Series of dates from the culture-bearing layer, including the date of soot from pottery fragments (Fig. 4), shows that the Kamskaya culture population habited this area about 5800-5710 cal $\mathrm{BC}$ and the dated ceramics is one of the oldest pottery findings in Northern Russia.

4) The Middle Neolithic habitants (Pezmogty 1, 3, 4, 5,
Lyalovskaya culture, $4710-4600$ cal BC) built the dwellings on the side of terrace adjacent to overgrowing lake. Nevertheless, both the shoreline of the lake and the river were rather far from known sites, so they existed relatively far from water sources (Fig. 6c). Probably this gives evidence that the dwellings were used during the winter season only. If this unexpected fact is confirmed by further research, it will make a new feature in our understanding of the subsistence of Neolithic population and its settling of Northern Russia.

5) The Bronze Age flint workshop (about 3940-2500 cal BC) was organized in deflation hollows in the same relation to river channel as Neolithic dwellings (Fig. 6c). Such location looks quite reasonable for a specialized processing site with a short-term exploitation period.

6) During Medieval Ages (XII-XIII c.), a burial ground with 19 studied graves functioned in the dune field at the east side of the terrace near swampy forest. The burial ground is assumed to have operated rather shortly, and the synchronous settlement has not yet been found. Geomorphic data and radiocarbon dating

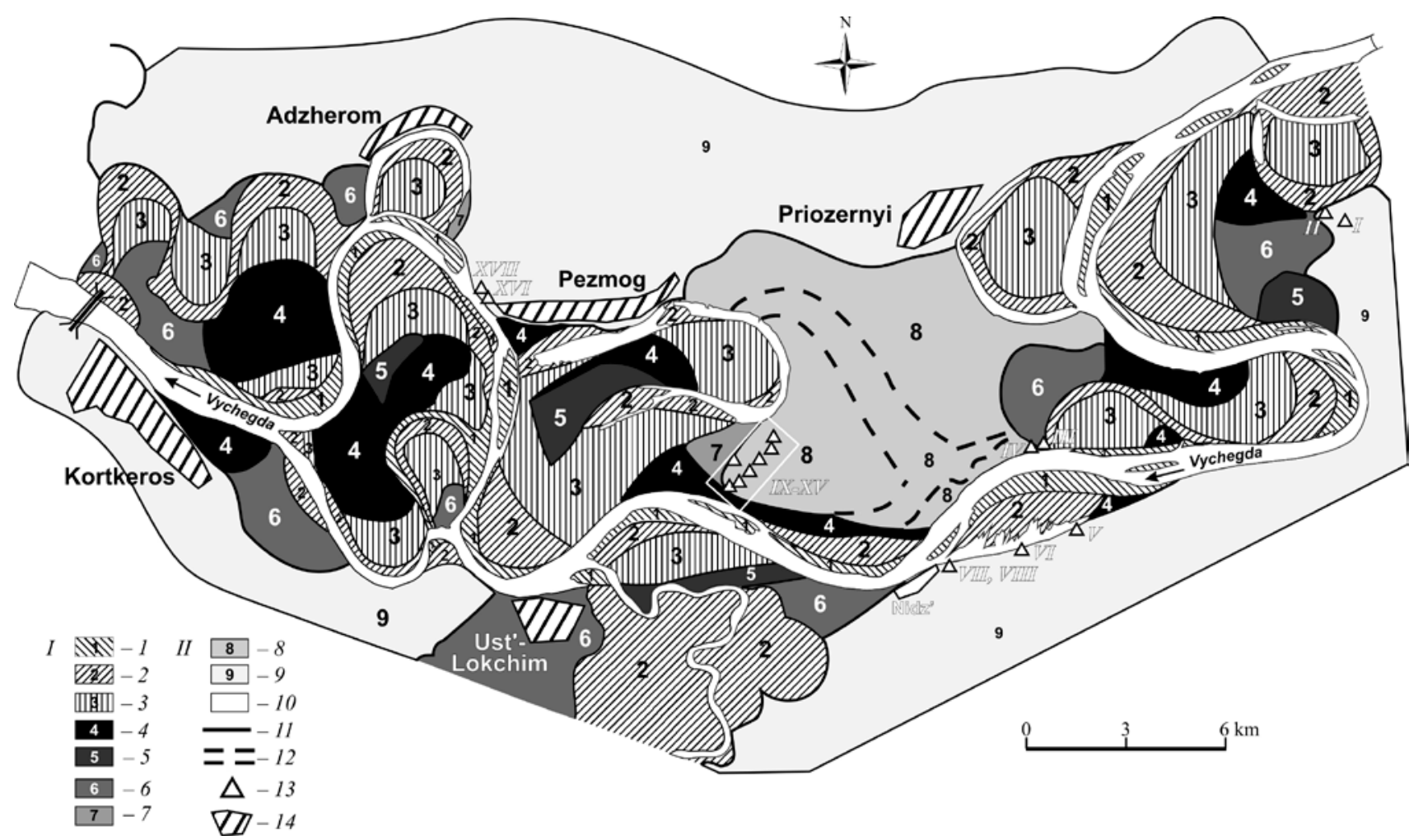

Fig. 5. Geomorphic map of the Vychegda River valley. I - Floodplain segments: 1 - modern (late SA); 2 -middle SA; 3 -early SA; 4 - SB; 5 - middle AT; 6 - early AT; 7 - early Bo; II - Fluvial terraces: 8 - 1st (8-10 m, Late Glacial, end of OIS 2); 9 - 2nd ( 30-35 m, end of Moscow (Varta) glaciation, OIS 6); 10 - modern river channel and oxbow lakes in the floodplain; 11 - cliffs of terraces; 12 - palaeochannels on the 1st terrace; 13 - archaeological sites; 14 - modern settlements.

Archaeological sites: I, II - Vazhkur'ya 1, 2; III - Pezmog 4; IV - Pezmog 2; V - Mortshuyaty 2; VI - Mortshuyaty 1; VII, VIII - Nidz' 1, 2; IX Pezmogty 1; X - Pezmogty 2; XI - Pezmogty 3; XII - Pezmogty 6; XIII - Pezmogty 4; XIV - Pezmogskiy burial ground; XV - Pezmogty 5; XVI Pezmog 3; XVII - Pezmog 1. 
Table 1. Radiocarbon dates from the middle Vychegda River valley (see location of particular No at Fig. 2). Bold: dates that correspond well to geomorphic age of floodplain/terrace unit; Italic: dates corresponding to local beginning of bog formation.

\begin{tabular}{|c|c|c|c|c|c|c|c|}
\hline $\begin{array}{l}\text { No.Geomorphic } \\
\text { position }\end{array}$ & $\begin{array}{l}\text { Lithology, } \\
\text { stratigraphy }\end{array}$ & $\begin{array}{l}\text { Depth } \\
\text { (m) }\end{array}$ & $\begin{array}{l}\text { Dated } \\
\text { material }\end{array}$ & $\begin{array}{l}\text { Lab } \\
\text { (GIN) } \\
\text { code }\end{array}$ & $\begin{array}{l}{ }^{14} \mathrm{C} \text { date, } \\
\mathrm{BP}\end{array}$ & $\begin{array}{c}\text { Calibrated age range, } \\
1 \sigma(68.2 \%)\end{array}$ & $\begin{array}{c}\text { Calibrated age range, } \\
2 \sigma(95.4 \%)\end{array}$ \\
\hline $\begin{array}{ll}1 & \begin{array}{l}\text { Floodplain palaeo- } \\
\text { channel, Pezmog } 4 \text { site }\end{array}\end{array}$ & Palaeochannel infill & $2.54-2.57$ & Loamy peat & 14200 & $4610 \pm 20$ & $\begin{array}{c}5220(8.8 \%) 5200 \mathrm{BC} \\
5180(59.4 \%) 5060 \mathrm{BC}\end{array}$ & $5300(95.4 \%) 5040 \mathrm{BC}$ \\
\hline $\begin{array}{ll}2 & \begin{array}{l}\text { Floodplain palaeo- } \\
\text { channel, Pezmog } 4 \text { site }\end{array} \\
\end{array}$ & Palaeochannel infill & $3.25-3.28$ & Loamy peat & 14201 & $6200 \pm 40$ & $\begin{array}{l}3490(38.6 \%) 3470 \mathrm{BC} \\
3380(29.6 \%) 3360 \mathrm{BC}\end{array}$ & $\begin{array}{l}3500(54.1 \%) 3450 \mathrm{BC} \\
3380(41.3 \%) 3350 \mathrm{BC}\end{array}$ \\
\hline $\begin{array}{ll}3 & \begin{array}{l}\text { Floodplain palaeo- } \\
\text { channel, Pezmog } 4 \text { site }\end{array} \\
\end{array}$ & Palaeochannel infill & $3.58-3.90$ & Loamy peat & 14202 & $6870 \pm 40$ & $5800(68.2 \%) 5710 \mathrm{BC}$ & $5850(95.4 \%) 5660 \mathrm{BC}$ \\
\hline $\begin{array}{ll}4 & \begin{array}{l}\text { st terrace, younger } \\
\text { part }\end{array} \\
\end{array}$ & $\begin{array}{l}\text { Clay, active channel } \\
\text { pool facies }\end{array}$ & 12.5 & $\begin{array}{l}\text { Peaty loam } \\
\text { (bulk) }\end{array}$ & 14189 & $10530 \pm 80$ & $10740(68.2 \%) 10440 \mathrm{BC}$ & 10850(95.4\%)10200BC \\
\hline $\begin{array}{l}5 \text { st terrace, younger } \\
\text { part }\end{array}$ & $\begin{array}{l}\text { Hard clay loam } \\
\text { interlayering with } \\
\text { fluvial sands }\end{array}$ & 12.8 & $\begin{array}{l}\text { Clay loam } \\
\text { with organic } \\
\text { (bulk) }\end{array}$ & 14190 & $12560 \pm 80$ & $\begin{array}{c}13030(63.9 \%) 12620 \mathrm{BC} \\
12590(4.3 \%) 12540 \mathrm{BC}\end{array}$ & $13150(95.4 \%) 12300 \mathrm{BC}$ \\
\hline $\begin{array}{l}6 \text { st terrace, younger } \\
\text { part }\end{array}$ & $\begin{array}{l}\text { Hard clay loam } \\
\text { interlayering with } \\
\text { fluvial sands }\end{array}$ & 13.2 & $\begin{array}{l}\text { Clay loam } \\
\text { with organic } \\
\text { (bulk) }\end{array}$ & 14192 & $13890 \pm 50$ & $14810(68.2 \%) 14390 \mathrm{BC}$ & $15000(95.4 \%) 14200 B C$ \\
\hline $\begin{array}{l}7 \text { st terrace, younger } \\
\text { part }\end{array}$ & $\begin{array}{l}\text { Clay, active channel } \\
\text { pool facies }\end{array}$ & 7.6-7.7 & Wood & 14019 & $10360 \pm 30$ & $\begin{array}{c}10400(12.3 \%) 10360 \mathrm{BC} \\
10350(6.3 \%) 10320 \mathrm{BC} \\
10290(49.6 \%) 10150 \mathrm{BC}\end{array}$ & 10440(95.4\%)10120BC \\
\hline $8 \begin{array}{l}1 \text { st terrace, younger } \\
\text { part }\end{array}$ & $\begin{array}{l}\text { Clay, active channel } \\
\text { pool facies }\end{array}$ & $6.78-6.8$ & Peat & 14023 & $11430 \pm 40$ & $11375(68.2 \%) 11290 \mathrm{BC}$ & $11430(95.4 \%) 11250 \mathrm{BC}$ \\
\hline $9 \begin{array}{l}1 \text { st terrace, younger } \\
\text { part }\end{array}$ & $\begin{array}{l}\text { Peaty clay loam } \\
\text { underlying fluvial } \\
\text { sands }\end{array}$ & 12.5 & $\begin{array}{l}\text { Peaty clay } \\
\text { loam } \\
\text { (bulk) }\end{array}$ & 14193 & $11000 \pm 40$ & $11005(68.2 \%) 10930 \mathrm{BC}$ & 11090(95.4\%)10910BC \\
\hline $\begin{array}{l}10 \begin{array}{l}1^{\text {st }} \text { terrace, younger } \\
\text { part }\end{array} \\
\end{array}$ & Logs in clay loams & 12.5 & Wood & 14194 & $10480 \pm 50$ & $\begin{array}{l}10690(57.3 \%) 10480 \mathrm{BC} \\
10470(10.9 \%) 10430 \mathrm{BC}\end{array}$ & 10750(95.4\%)10200BC \\
\hline $\begin{array}{l}11 \text { st terrace, younger } \\
\text { part }\end{array}$ & Logs in clay loams & 12.5 & Wood & 14195 & $10300 \pm 50$ & $\begin{array}{c}10290(4.8 \%) 10250 \mathrm{BC} \\
10220(63.4 \%) 10030 \mathrm{BC}\end{array}$ & $\begin{array}{c}10450(92.0 \%) 10000 \mathrm{BC} \\
9950(3.4 \%) 9850 \mathrm{BC}\end{array}$ \\
\hline $12{ }_{\text {part }}^{\text {st terrace, younger }}$ & Logs in clay loams & 10.8 & Loam (bulk) & 14198 & $11560 \pm 50$ & $11500(68.2 \%) 11370 \mathrm{BC}$ & $11600(95.4 \%) 11320 \mathrm{BC}$ \\
\hline 13 Floodplain hollow & Base of cover peat & 1.08 & Peat & 14199 & $5150 \pm 30$ & $\begin{array}{c}4035(1.8 \%) 4025 \mathrm{BC} \\
3990(66.4 \%) 3940 \mathrm{BC}\end{array}$ & $\begin{array}{c}4040(8.7 \%) 4010 \mathrm{BC} \\
4000(72.8 \%) 3930 \mathrm{BC} \\
3880(14.0 \%) 3800 \mathrm{BC}\end{array}$ \\
\hline $\begin{array}{l}\text { Palaeochannel on the } \\
141^{\text {st terrace, younger }} \\
\text { part }\end{array}$ & $\begin{array}{l}\text { Base of palaeochan- } \\
\text { nel infill }\end{array}$ & $3.55-3.7$ & Peat & 14039 & $10400 \pm 150$ & $10700(68.2 \%) 10050 \mathrm{BC}$ & $10900(95.4 \%) 9800 \mathrm{BC}$ \\
\hline 15 Floodplain hollow & Overbank facies & 4.40 & Loamy peat & 14203 & $6550 \pm 30$ & $5525(68.2 \%) 5475 \mathrm{BC}$ & $\begin{array}{c}5610(1.0 \%) 5590 \mathrm{BC} \\
5560(94.4 \%) 5470 \mathrm{BC}\end{array}$ \\
\hline 16 Floodplain hollow & Overbank facies & 4.9 & Loamy peat & 14204 & $7640 \pm 40$ & $\begin{array}{l}6560(0.9 \%) 6550 \mathrm{BC} \\
6510(67.3 \%) 6430 \mathrm{BC}\end{array}$ & $6590(95.4 \%) 6430 \mathrm{BC}$ \\
\hline 17 Floodplain hollow & Overbank facies & 5.95 & Wood log & 14205 & $6420 \pm 140$ & $\begin{array}{c}5520(60.4 \%) 5280 \mathrm{BC} \\
5270(7.8 \%) 5220 \mathrm{BC} \\
\end{array}$ & $5650(95.4 \%) 5050 \mathrm{BC}$ \\
\hline $18 \begin{array}{l}\text { Inter-levee hollow } \\
\text { covered by peat }\end{array}$ & Base of cover peat & $1.38-1.4$ & Loamy peat & 14044 & $4100 \pm 30$ & $\begin{array}{l}2850(14.6 \%) 2810 \mathrm{BC} \\
2680(53.6 \%) 2570 \mathrm{BC}\end{array}$ & $\begin{array}{l}2870(21.9 \%) 2800 \mathrm{BC} \\
2760(72.2 \%) 2560 \mathrm{BC} \\
2520(1.3 \%) 2500 \mathrm{BC} \\
\end{array}$ \\
\hline $\begin{array}{l}20 \begin{array}{l}\text { 1st terrace, older part, } \\
\text { peat bog }\end{array} \\
\end{array}$ & $\begin{array}{l}\text { Base of Holocene } \\
\text { peat }\end{array}$ & $3.0-3.6$ & Peat & 14025 & $0 \pm 30$ & $\begin{array}{l}8210(16.6 \%) 8160 \mathrm{BC} \\
8120(51.6 \%) 7980 \mathrm{BC}\end{array}$ & $8230(95.4 \%) 7960 \mathrm{BC}$ \\
\hline $\begin{array}{l}191^{1^{\text {st }}} \text { terrace, older part, } \\
\text { peat bog }\end{array}$ & Holocene peat & $2.1-2.2$ & Peat & 14027 & $5970 \pm 20$ & $\begin{array}{l}4900(29.5 \%) 4865 \mathrm{BC} \\
4855(26.0 \%) 4825 \mathrm{BC} \\
4815(12.7 \%) 4800 \mathrm{BC}\end{array}$ & 4940(95.4\%)4790BC \\
\hline $\begin{array}{l}\text { Palaeochannel on the } \\
211^{\text {st terrace, older part, }} \\
\text { peat bog }\end{array}$ & Holocene peat & $2.15-2.25$ & Peat & 14035 & $3970 \pm 40$ & $\begin{array}{l}2570(37.1 \%) 2510 B C \\
2500(31.1 \%) 2460 B C\end{array}$ & $2580(95.4 \%) 2340 \mathrm{BC}$ \\
\hline $\begin{array}{l}\text { Palaeochannel on the } \\
221^{\text {st terrace, older part, }} \\
\text { peat bog }\end{array}$ & Holocene peat & $2.8-2.9$ & Wood & 14033 & $4690 \pm 40$ & $\begin{array}{l}3520(15.0 \%) 3490 \mathrm{BC} \\
3470(53.2 \%) 3370 \mathrm{BC}\end{array}$ & $\begin{array}{l}3630(14.9 \%) 3580 \mathrm{BC} \\
3540(80.5 \%) 3360 \mathrm{BC}\end{array}$ \\
\hline $\begin{array}{l}\text { Palaeochannel on the } \\
231^{\text {st terrace, older part, }} \\
\text { peat bog }\end{array}$ & Holocene peat & $3.15-3.25$ & Peat & 14036 & $5020 \pm 30$ & $\begin{array}{l}3940(37.5 \%) 3870 \mathrm{BC} \\
3810(28.5 \%) 3760 \mathrm{BC} \\
3730(2.2 \%) 3710 \mathrm{BC}\end{array}$ & 3950(95.4\%)3700BC \\
\hline
\end{tabular}


Table 1. Continuation.

\begin{tabular}{|c|c|c|c|c|c|c|c|}
\hline $\begin{array}{l}\text { No.Geomorphic } \\
\text { position }\end{array}$ & $\begin{array}{l}\text { Lithology, } \\
\text { stratigraphy }\end{array}$ & $\begin{array}{l}\text { Depth } \\
\text { (m) }\end{array}$ & $\begin{array}{l}\text { Dated } \\
\text { material }\end{array}$ & $\begin{array}{l}\text { Lab } \\
\text { (GIN) } \\
\text { code }\end{array}$ & $\begin{array}{l}{ }^{14} \mathrm{C} \text { date, } \\
\mathrm{BP}\end{array}$ & $\begin{array}{c}\text { Calibrated age range, } \\
1 \sigma(68.2 \%)\end{array}$ & $\begin{array}{c}\text { Calibrated age range, } \\
2 \sigma(95.4 \%)\end{array}$ \\
\hline 24 Palaeochannel & Palaeochannel infill & 3.4-3.5 & Loamy peat & 14031 & $5230 \pm 50$ & $\begin{array}{l}4230(4.4 \%) 4200 \mathrm{BC} \\
4160(7.8 \%) 4130 \mathrm{BC} \\
4060(56.1 \%) 3960 \mathrm{BC} \\
\end{array}$ & $\begin{array}{c}4230(9.2 \%) 4190 \mathrm{BC} \\
4180(86.2 \%) 3950 \mathrm{BC}\end{array}$ \\
\hline $\begin{array}{l}\text { Palaeochannel on the } 1^{\text {st }} \\
25 \text { terrace, older part, peat } \\
\text { bog }\end{array}$ & Holocene peat & 4.0-4.1 & Peat & 14037 & $5900 \pm 40$ & $\begin{array}{c}4830(5.5 \%) 4810 \mathrm{BC} \\
4800(62.7 \%) 4720 \mathrm{BC}\end{array}$ & $\begin{array}{c}4900(1.8 \%) 4860 \mathrm{BC} \\
4850(93.6 \%) 4680 \mathrm{BC}\end{array}$ \\
\hline $\begin{array}{l}\text { Palaeochannel on the } 1^{\text {st }} \\
26 \text { terrace, older part, peat } \\
\text { bog }\end{array}$ & Base of Holocene peat & $4.35-4.45$ & Peat & 14038 & $8550 \pm 40$ & $7595(68.2 \%) 7550 \mathrm{BC}$ & $7595(68.2 \%) 7550 \mathrm{BC}$ \\
\hline $\begin{array}{l}271^{\text {st terrace, older part, }} \\
\text { peat bog }\end{array}$ & Base of peat & $3.8-3.9$ & Peat & 14034 & $7880 \pm 60$ & $\begin{array}{c}6910(4.2 \%) 6880 \mathrm{BC} \\
6830(64.0 \%) 6640 \mathrm{BC}\end{array}$ & $7030(95.4 \%) 6600 \mathrm{BC}$ \\
\hline $\begin{array}{l}28 \text { Inter-levee hollow cov- } \\
\text { ered by peat }\end{array}$ & Base of cover peat & $1.03-1.05$ & Loamy peat & 14043 & $1720 \pm 20$ & $\begin{array}{c}250(34.3 \%) 300 \mathrm{AD} \\
320(25.5 \%) 350 \mathrm{AD} \\
360(8.5 \%) 380 \mathrm{AD}\end{array}$ & $250(95.4 \%) 390 \mathrm{AD}$ \\
\hline 29 Floodplain & $\begin{array}{l}\text { Overbank facies, } \\
\text { buried palaeosoil }\end{array}$ & $0.42-0.44$ & Humus & 14182 & $840 \pm 40$ & $1160(68.2 \%) 1255 \mathrm{AD}$ & $\begin{array}{l}\text { 1040(7.4\%)1090AD } \\
1120(2.1 \%) 1140 \mathrm{AD} \\
1150(85.8 \%) 1280 \mathrm{AD}\end{array}$ \\
\hline 30 Floodplain hollow & $\begin{array}{l}\text { Middle of peat layer } \\
\text { enclosed into the } \\
\text { hollow }\end{array}$ & 0.6 & Peat & 14184 & $1700 \pm 30$ & $\begin{array}{l}260(12.9 \%) 280 A D \\
320(55.3 \%) 400 A D\end{array}$ & $250(95.4 \%) 420 \mathrm{AD}$ \\
\hline 31 Floodplain hollow & Base of peat & 0.95 & Loamy peat & 14185 & $3200 \pm 40$ & $1505(68.2 \%) 1430 \mathrm{BC}$ & $\begin{array}{c}1610(2.7 \%) 1570 \mathrm{BC} \\
1540(92.7 \%) 1390 \mathrm{BC}\end{array}$ \\
\hline $\begin{array}{l}\text { Inter-levee hollow cov- } \\
32 \text { ered by peat }\end{array}$ & Base of cover peat & 0.75 & Loamy peat & 14041 & $2270 \pm 40$ & $\begin{array}{l}400(33.5 \%) 350 \mathrm{BC} \\
290(34.7 \%) 230 \mathrm{BC}\end{array}$ & $\begin{array}{l}400(39.6 \%) 340 \mathrm{BC} \\
330(55.8 \%) 200 \mathrm{BC}\end{array}$ \\
\hline 33 floodplain hollow & Overbank facies & $1.45-1.55$ & Charcoal & 14186 & $940 \pm 40$ & $\begin{array}{l}\text { 1033(5.5\%)1054AD } \\
\text { 1078(62.7\%)1153AD }\end{array}$ & 1019(95.4\%)1185AD \\
\hline 34 Palaeochannel & $\begin{array}{l}\text { Base of palaeochan- } \\
\text { nel infill }\end{array}$ & $3.0-3.1$ & Peat & 14029 & $9490 \pm 50$ & $\begin{array}{c}9120(9.5 \%) 9070 \mathrm{BC} \\
9060(8.3 \%) 9010 \mathrm{BC} \\
8840(49.6 \%) 8710 \mathrm{BC} \\
8670(0.8 \%) 8650 \mathrm{BC}\end{array}$ & $\begin{array}{l}9130(26.5 \%) 8990 \mathrm{BC} \\
8930(68.9 \%) 8630 \mathrm{BC}\end{array}$ \\
\hline 35 Flood plain, hollow & Overbank facies & $1.67-1.82$ & $\begin{array}{l}\text { Loamy peat } \\
\text { (bulk) }\end{array}$ & $14189 a$ & $8860 \pm 70$ & $\begin{array}{l}8210(63.6 \%) 7910 \mathrm{BC} \\
7900(4.6 \%) 7870 \mathrm{BC}\end{array}$ & $8240(95.4 \%) 7740 \mathrm{BC}$ \\
\hline 36 Inter-levee hollow & $\begin{array}{l}\text { Base of overbank } \\
\text { facies }\end{array}$ & $3.15-3.25$ & Loamy peat & 14030 & $2380 \pm 130$ & $\begin{array}{l}760(13.0 \%) 680 \mathrm{BC} \\
670(55.2 \%) 370 \mathrm{BC}\end{array}$ & $800(95.4 \%) 150 \mathrm{BC}$ \\
\hline $\begin{array}{l}37 \text { Inter-levee hollow cov- } \\
\text { ered by peat }\end{array}$ & Base of cover pelt & 1.55 & Loamy peat & 14048 & $3240 \pm 40$ & $\begin{array}{c}1610(6.5 \%) 1580 \mathrm{BC} \\
1540(61.7 \%) 1440 \mathrm{BC}\end{array}$ & 1620(95.4\%)1430BC \\
\hline $\begin{array}{l}38 \text { Inter-levee hollow cov- } \\
\text { ered by peat }\end{array}$ & Base of cover peat & $1.43-1.45$ & Loamy peat & 14047 & $3720 \pm 70$ & $\begin{array}{l}2270(2.6 \%) 2250 \mathrm{BC} \\
2210(63.8 \%) 2020 \mathrm{BC} \\
2000(1.8 \%) 1980 \mathrm{BC}\end{array}$ & $2340(95.4 \%) 1910 \mathrm{BC}$ \\
\hline 39 Flood plain, hollow & Overbank facies & 1.8 & Wood & 14187 & $1820 \pm 110$ & $70(68.2 \%) 340 \mathrm{AD}$ & $50(95.4 \%) 550 \mathrm{AD}$ \\
\hline $\begin{array}{l}40 \begin{array}{l}\text { Floodplain palaeochan- } \\
\text { nel }\end{array}\end{array}$ & Palaeochannel infill & $0.82-0.94$ & $\begin{array}{l}\text { Plant } \\
\text { macrofossils }\end{array}$ & 14183 & $860 \pm 70$ & $\begin{array}{c}\text { 1050(13.2\%)1090AD } \\
\text { 1120(4.1\%)1140AD } \\
1150(50.9 \%) 1260 A D\end{array}$ & $\begin{array}{c}\text { 1050(13.2\%)1090AD } \\
\text { 1120(4.1\%)1140AD } \\
1150(50.9 \%) 1260 A D\end{array}$ \\
\hline 41 Pezmogty oxbow lake & $\begin{array}{l}\text { Base of palaeochan- } \\
\text { nel infill }\end{array}$ & $2.9-3.0$ & Gyttja & $14039 a$ & $2170 \pm 100$ & $370(68.2 \%) 110 \mathrm{BC}$ & $410(95.4 \%) 30 \mathrm{AD}$ \\
\hline 42 Floodplain hollow & Overbank facies & $0.15-0.24$ & Wood twigs & 14206 & $9460 \pm 40$ & $\begin{array}{c}1020(6.4 \%) 1060 \mathrm{AD} \\
1070(51.8 \%) 1160 \mathrm{AD}\end{array}$ & 1010(95.4\%)1190AD \\
\hline
\end{tabular}


of the base of oxbow deposits (no. 41 in Table 1 and Fig. 2) provide the evidence that modern lake Pezmogty already existed at that time. Therefore the lake shoreline has been stable over the last 2000 years, and the required settlement is probable to be found at the lake shores in the vicinity of the burial place (Fig. 6d). It should be noted that the position of Pezmogskiy burial ground is typical for medieval burials of European North-East and confirms the peculiarity of ritual practice of komi' ancestors once more.

7) Formation of the modern oxbow lake Pezmogty took place about 370-110 cal BC. Therefore the Pezmog village - the first historical settlement founded at the end of XVIth c. was initially located at the bank of oxbow lake rather than at the river bank as it is reflected in folklore of native people. Good connection of the lake to the river must have been a positive factor promoting selection of the place (Fig. 6d).

8) Further period of human settling was connected with GULAG-system and foundation of so called special settlements for logging (Adzherom, Priozernyj and Nidz') and timber floating (Ust'-Lokchim). Major factors of settlement location were proximity to woodlands and access to the river as a transport route for timber (Fig. 2).
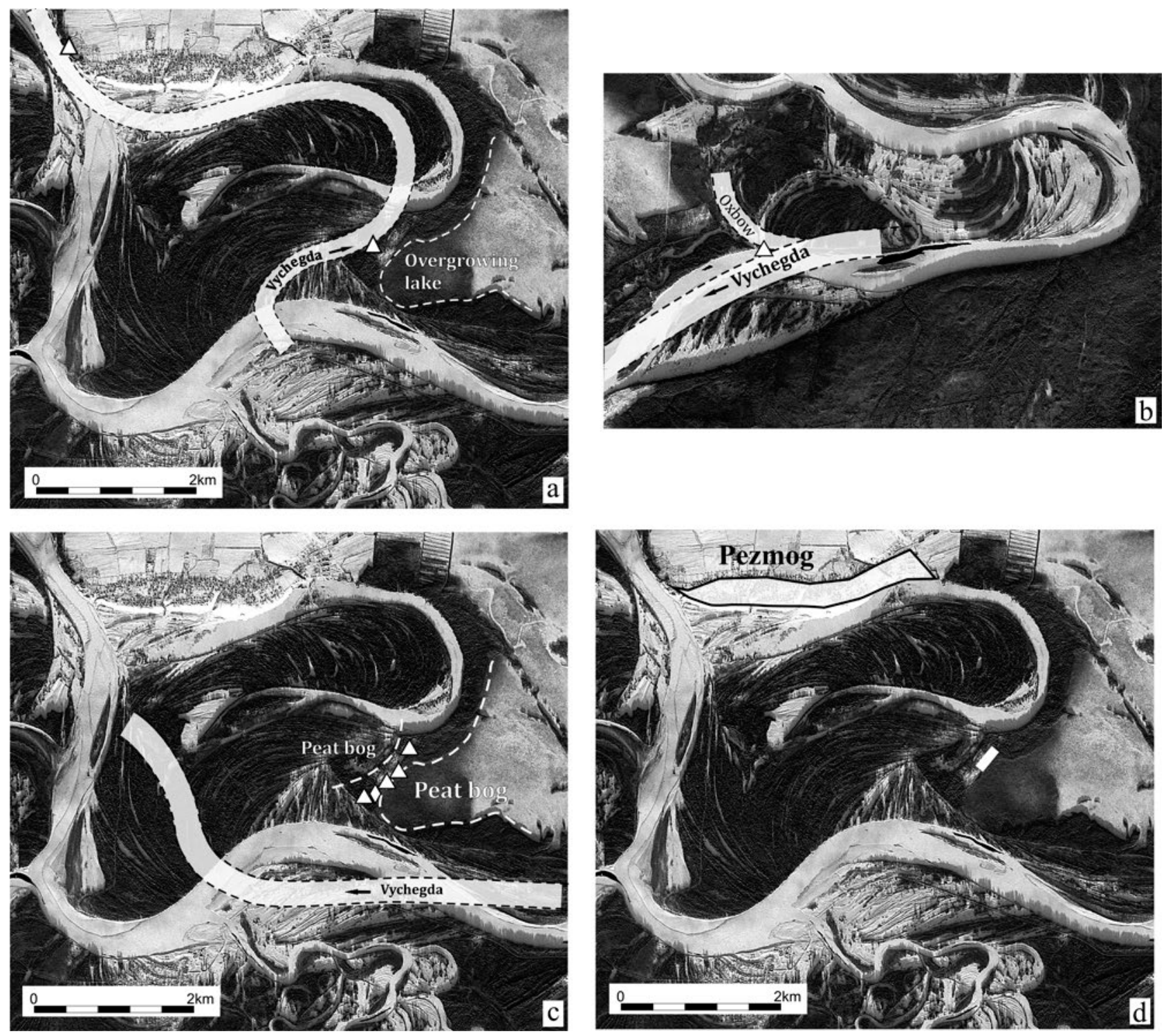

Fig. 6. Archaeological sites in different periods in the context of synchronous valley. 1 - Mesolithic (temporary camps, about 9.0 kyr BP); $2-$ early Neolithic (temporary camp, 6.8 kyr BP); 3 - middle Neolithic (seasonal dwellings, 5.8 kyr BP) and early Bronze Age (flint workshop, 4.0-5.0 kyr BP); 4 - Medieval Ages (burial, XII-XIII c. AD) and modern situation (Pezmog village, date of foundation - end of XVI C. AD). 


\section{CONCLUSION AND PERSPECTIVES}

According to archaeological evidence and historical records we define seven periods of human settling in the studied part of the Vychegda River valley: 1) Mesolithic; 2) Early Neolithic; 3) Middle Neolithic; 4) Early Bronze Age; 5) Medieval time; 6) Late Medieval; 7) Modern time. All discovered camps and dwellings functioned about one season or less. Even komi farmer' village (Pezmog), founded at end of XVIth c. AD, was once abandoned by people because of bad harvest in the middle of XVIIth c. AD. In modern time the special settlements of loggers loses their specialty and population. Periods of human habitation here were episodic and short-term, and during long time spans the region was unsettled. Between the periods of human occupation, local landscapes were changing because of active fluvial processes. Therefore new settlers discovered somewhat different landscapes than previous ones. To reconstruct these landform changings, geomorphic map was composed showing different age generations of palaeochannels and floodplain segments. It was added by radiocarbon dating of the Late Pleistoscene-Holocene sediments of Vychegda river valley. On this base, spatial-temporal correlation between periods of human occupation and landscape changing events is defined.

Mainly archaeological sites and present settlements were organized on terraces and correspond to synchronous active river channels or oxbow lakes connected to the river. Few exceptions exist which are explained by peculiarity of ritual burial practice (Pezmogskiy burial ground), probable winter functioning of dwellings (Pezmogty 1, 3, 4, 5) or specialization of settlements (Ust'-Lokchim). Due to analysis of geomorphic map directions of further archaeological survey of differentage settlements, especially Palaeolithic and medieval sites, are determined. Undoubtedly reconstruction of local environments of ancient and medieval population improves the quality of archaeological data. The results will serve as the base for the study of subsistence features and adaptation system of human groups in the Russian North. Nevertheless, in some cases interpretation of the results is discussion. It concerns mainly the Neolithic dwellings position far from sources of water as a part of human subsistence. Verification of these data is needed by research of similar objects in the same conditions. More detailed analysis of obtained data and expansion of geographic borders of studied territory are planned also. For instance, correspondence of the above results with sporepollen and botanic data is needed for reconstruction of local climate changing.

\section{REFERENCES}

Brown AG, 2003. Time, space and casuality of floodplain palaeoecology. In: Howard AJ, Macklin MG and Passmore DG, eds., Alluvial Archaeology in Europe. Proceedings of the alluvial archaeology of
North-West Europe and Mediteranian, 18-19 December 2000, Leeds, UK. Lisse: 15-24.

Burov GM, 1967. Drevnij Sindor (Iz istorii plemen Evropeiskogo Severo-Vostoka v VII tysyacheletii do n.e. - I tysyacheletii n.e.). (Ancient Sindor. From history of European North-East tribes in VIIth m. BC - Ist m. AD). Moscow, Nauka: 210pp (in Russian).

Burov GM, Romanova EN and Sementsov AD, 1972. Hronologiya derevyannyh sooruzhenij i veschej, naidennyh $\mathrm{v}$ Severodvinskom bassejne. Problemy absolyutnogo datirovaniya v arheologii (Chronology of wooden buildings and artifacts, found in North Dvina river basin. In: The problems of absolute dating in archaeology). Moscow, Nauka: 76-79 (in Russian).

Dobrzanska G, Jerem E and Kalicki T, eds., 2004. The Geoarchaeology of River Valleys. Archaeolingua. Series Minor. Budapest: 7-8.

Howard AJ, Macklin MG and Passmore DG, 2003. Preface. In: Howard AJ, Macklin MG and Passmore DG, eds., Alluvial Archaeology in Europe. Proceedings of the alluvial archaeology of North-West Europe and Mediteranian. 18-19 December 2000, Leeds, UK. Lisse: IX-X.

Karmanov VN, 2008. Neolit evropeiskogo Severo-Vostoka (Neolithic of European North-East). Syktyvkar: 226pp (in Russian).

Korolev KS, 1980. Pezmogskij mogil'nik. In: Drevnie pamyatniki Severnogo Priural'ya (Pezmog burial ground). In: Ancient sites of Northern Subural. Syktyvkar: 116-124 (in Russian).

Korolev KS, 2005. Razvedochnye raboty na srednei Vychegde. In: Pamyatniki epohi kamnya, rannego metalla i srednevekov'ya evropeiskogo Severo-Vostoka (Prospection on Middle Vychegda). In: Savelieva EA, Karmanov VN, eds., The sites of Stone Age, Palaeometal and Medieval Ages of European North-East. Syktyvkar: $145-154$ (in Russian).

Reimer PJ, Baillie MGL, Bard E, Bayliss A, Beck JW, Blackwell PG, Bronk Ramsey C, Buck CE, Burr G, Edwards RL, Friedrich M, Grootes PM, Guilderson TP, Hajdas I, Heaton TJ, Hogg AG, Hughen KA, Kraiser KF, Kromer B, McCormac FG, Manning S, Reimer RW, Richards DA, Southon JR, Talamo S, Turney CSM, van der Plicht J, Weyhenmeyer CE, 2009. IntCal09 and Marine09 radiocarbon age calibration curves, $0-50,000$ years cal BP. Radiocarbon 51: 1111-1150.

Volokitin AV and Tkachev YA, 2004. Reconstruction of environment of the Mesolithic population of Vychegda river. In: Archaeology, ethnology and anthropology of Eurasia, 2: 2-10.

Volokitin AV, Zaretskaya NE and Karmanov VN, 2006. Novye dannye po hronologii kamskoi neoliticheskoi kul'tury (New data on the chronology of Kama Neolithic culture). In: Rossiiskaya arheologiya 1: 137-142 (in Russian).

Zagainova GV, 2001. Plotnost' naseleniya. (Density of population) In: Savelieva, eds., Atlas of Komi Republic. Moscow, DIK: 424-425 (in Russian).

Zaretskaya NE, Volokitin AV, Karmanov VN and Uspenskaya ON, 2007. Novye dannye po radiouglerodnoi hronologii i palaeogeografii Sindorskogo geoarheologicheskogo mikroraiona (New data on the radiocarbon dating and palegeography of Sindor geoarchaeological region). In: Volokitin AV, Karmanov VN and Pavlov PY, eds., Stone age of European North. Syktyvkar: 148-160 (in Russian).

Zaretskaya NE, Chernov AV, Karmanov VN, Panin AV, Buravskaya MN and Volokitin AV, 2009. Opyt rekonstruktsii istorii doliny srednej Vychegdy v pozdnelednikov'e i golotsene po rezul'tatam kompleksnyh issledovanij. V: Materialy VI Vserossiiskogo soveschaniya po izucheniyu chetvertichnogo perioda (Experience of Vychegda valley history reconstruction in the Late GlacialHolocene on the results of inter-disciplinary research. In: Materials of VIth All-Russian conference on Quaternary studies. 18-23 October 2009, Novosibirsk). Novosibirsk: 223-226 (in Russian).

Zherebtsov IL, 2001. Naselennye punkty Respubliki Komi. Istorikodemograficheskii spravochnik (Settlements of Komi Republic. Historical and demographic manual). Moscow, Nauka: 580pp (in Russian). 